\title{
Risk factors for stress among police officers: A systematic literature review
}

\author{
Petros Galanis*, Despoina Fragkou and Theodoros A. Katsoulas \\ Department of Nursing, National and Kapodistrian University of Athens, Athens, Greece
}

Received 12 January 2019

Accepted 26 January 2020

\begin{abstract}
.
BACKGROUND: Stress is common among police personnel leading to several negative consequences.

OBJECTIVE: We performed a systematic literature review to identify risk factors for stress among police officers.

METHODS: We searched PubMed and Scopus electronic databases through to July 2018 and we conducted this review according to the Preferred Reporting Items for Systematic Reviews and Meta-Analyses (PRISMA) statement. The NewcastleOttawa scale was used for studies quality assessment.

RESULTS: After selection, 29 cross-sectional studies met the inclusion criteria and included in the review. The average quality of studies was low since no study was rated as having low risk of bias, three studies (10.3\%) as moderate risk and 26 studies $(89.7 \%)$ were rated as having high risk of bias. Stress risk factors were summarized in the following categories: demographic characteristics; job characteristics; lifestyle factors; negative coping strategies and negative personality traits. CONCLUSIONS: Identification of stress risk factors is the first step to create and adopt the appropriate interventions to decrease stress among police personnel. The early identification of police officers at higher risk and the appropriate screening for mental health disorders is crucial to prevent disease and promote quality of life.
\end{abstract}

Keywords: Police work, job characteristics, coping strategies

\section{Introduction}

Stress is a dynamic process resulting from external pressure on most occasions [1]. A broad and multilevel concept such as stress requires the incorporation of knowledge from several sciences (from neuroscience and biology to psychology and sociology) in order to be explained [2]. There is a continuous debate regarding the most appropriate way to define and conceptualize stress without yet a universal accepted definition of term. The most important feature of stress is the adaptation of an individual to environmental conditions that change over time [2]. Thus, the individual, the environment and time and their interaction are the core concepts of stress [3,4].

\footnotetext{
*Address for correspondence: Galanis Petros, 123 Papadiamantopoulou St., GR-11527, Athens, Greece. Tel.: +30 0030210 7781044, 00306944387354; E-mail:pegalan@nurs.uoa.gr.
}

Differences in the personality and the experiences of individuals could lead to different responses in either positive or negative stressors [5]. Positive stress is produced after the appropriate response to every day stressors. In contrast, failure of an individual to response adequately to stress can produce negative stress. Positive stress makes an individual feels excited in situations like starting a new job, getting married, and having a child. An individual experiences negative stress when she/he is unable to cope with situations like the death of a family member, the divorce, the loss of a job, and a chronic illness. Feeling stressed can be a normal and beneficial situation motivating individuals to focus on work and be productive, while too much stress can be painful and even catastrophic, resulting on depression and other health problems. Thus, positive stress can be useful and motivating, while negative stress can be devastating and detrimental. 
Adverse working conditions such as long working hours, shift work, extreme physical workload, noise, time pressure, limited rewards (salary, opportunities and esteem) and occupational hazards can result in work-related stress that increases the risk of diseases (type 2 diabetes, cardiovascular diseases, musculoskeletal complaints and periodontal diseases) [6-8]. Moreover, work-related stress is associated with decreased productivity and increased absenteeism and medical and health care cost due to the increased number of patients with mental health disorders $[9,10]$. Work-related stress occurs when the demands from the work environment exceed the workers' abilities and resources to deal with this demands resulting on discordance in the expectations between the workers and the organizations $[11,12]$. Certainly, work is only one aspect of life that can produce negative stress since there are many others stressful life events (e.g. school life, family issues, love and marriage, having children, social activities, health and financial issues) that can give rise to the experience of negative stress $[13,14]$. Although there is an interaction between the life stressors and the job-related stressors, it is not always obvious, making the understanding of stress more complicated [11, 12]. Stress tends to be multidimensional in nature, reflecting psychological and physical responses to environmental stressors [15], and should be recognized and treated early since otherwise it can produce a state of anxiety that if maintained can result on mental disease [16].

Police work is a high stress and challenging occupation, and police officers constitute a high-risk group for mental health morbidities such as post-traumatic stress disorder, anxiety disorders, depression, suicidal thoughts and behaviors [17-19]. Police officers experience significant job-related stressors and exposures such as violence, work injuries, job pressure and demand, lack of support, physical threats in operational field, long working hours, burnout and fatigue. These job-related stressors and exposures increase risk of poor mental health [20-23], and negative consequences such as increased risk of metabolic syndrome, hypertension, obesity and dyslipidaemia, smoking, alcohol and drug abuse, poor sleep quality, decreased quality of life and job satisfaction [24, 29-35]. In particular, job-related stressors and exposures increase stress, anxiety and irritability among police officers resulting on reduced productivity, absenteeism and worse quality of life [24-28]. Police officers contribute to the safety of society and there is a need to protect and improve their mental and physical health. In that case, identification of sources of stress through valid research is extremely important since then it is given the chance to create and adapt the appropriate interventions and strategies in order to decrease modifiable sources of stress and so on stress.

To the best of our knowledge, no systematic literature review exists addressing the risk factors for stress among police officers. Therefore, we performed a systematic literature review to find out stress risk factors among police officers. As mentioned earlier, stress is a broad and multilevel concept that is used with different meanings in the literature. Thus, we decided to focus on studies that measure life stress and job-related stress in order to be as comprehensive as possible. Moreover, within the context of this review, stress will only be considered as a negative psychological state.

\section{Material and methods}

\subsection{Search strategy}

We conducted this review according to the Preferred Reporting Items for Systematic Reviews and Meta-Analyses (PRISMA) statement (36). We searched PubMed (from 1946) and Scopus (from 1966) electronic databases through to July 2018, to identify relevant studies. We used PICO approach $[37,38]$ to identify the appropriate search terms and we used the following algorithm in all fields: (("police officer*" OR police OR "police force" OR "police service*") AND ("risk factor" " OR factor* OR determinant* OR stressor*) AND (stress OR "occupational stress" OR distress OR "work stress" OR "work-related stress" OR "job stress")). We used a great number of search terms and the wild card term "**" to improve the sensitivity of the search strategy. Two independent reviewers (DF and TK) evaluated the articles, while disagreements were discussed and resolved by consensus with a third reviewer (PG). The references of selected articles were searched to identify further appropriate studies. Our review was not prospectively registered.

\subsection{Inclusion and exclusion criteria}

There were no limits regarding participant characteristics, publication status or publication date. We included original studies that met the following inclusion criteria: (1) life stress or job-related stress was 
the outcome variable independently the way that was measured, (2) stress was assessed separately from anxiety, depression or other psychological symptoms, (3) any stress risk factors were the independent variables (e.g. demographic and job characteristics, lifestyle risk factors etc.), (4) studies published in peer-reviewed journals, (5) studies were published in English, (6) studies with quantitative data, (7) we searched on PubMed from 1946 and Scopus from 1966 through to July 2018, and (8) study populations included police officers. We excluded studies that did not meet these inclusion criteria and studies with posttraumatic stress disorder as the outcome variable.

\subsection{Data extraction}

We extracted the following information from each paper: first author's name; year of publication; country of study; study design; year of data collection; number of participants; risk factors measure (including questionnaire); outcome measure (including questionnaire); level of analysis (univariate or multivariate); and measures of effect and precision (e.g. coefficient beta, correlation coefficient, $p$-values, $95 \%$ confidence interval). Meta-analysis was considered but rejected due to high heterogeneity of studies on risk factors and stress measurement, level of analysis, measures of effect and precision and quality (risk of bias).

\subsection{Risk of bias assessment}

Two authors (PG and DF) performed independently an assessment of bias in the included studies using the Newcastle-Ottawa quality assessment scale adapted for cross-sectional studies since all studies in our review were cross-sectional [39, 40]. The Newcastle-Ottawa scale has the following three components assessing bias in the studies: selection; comparability; outcome assessment. Each study was assigned stars for items within each component for a maximum of ten stars, i.e. five stars for selection, two stars for comparability and three stars for outcome assessment. We chose to quantify the risk of bias by summing up the stars that each study was assigned in order to get a summary of bias even though there is not specific cut-off points for the Newcastle-Ottawa scale in case of cross-sectional studies. Accordingly, we decided to rate studies as high risk of bias if they received seven stars or less, moderate risk of bias if they received eight or nine stars and low risk of bias if they received ten stars, that corresponded to the highest methodological quality.

\section{Results}

\subsection{Study selection}

The search on PubMed and Scopus returned 568 and 19,791 records respectively. After removal of duplicates, 19,904 records remained and 19,635 were excluded at first screening (title/abstract), leaving 269 full-text articles assessed for eligibility. No additional records identified through other sources. Finally, 29 studies met the inclusion criteria and included in the systematic review. The flowchart of systematic literature review was constructed according to the PRISMA statement (36) and is presented in Fig. 1.

\subsection{Study characteristics}

A summary of studies included in the review is presented in the Appendix. All studies were crosssectional, the number of participants ranged from 102 to 3272 , and the percentage of males ranged from $58 \%$ to $100 \%$. Studies were published between 1985 and 2018 and were conducted in USA (11 studies), United Kingdom (3 studies), India (3 studies), Italy (2 studies), South Korea, Malaysia, Norway, Lithuania, Jamaica, France, China, Canada, Spain, and Switzerland.

Multivariate analysis to eliminate confounders was used in 20 studies [21, 23, 31, 41-57], while univariate analysis without taking confounders into consideration was used in nine studies [22, 58-65]. Different confounders were eliminated in each study and summarization of them in the review would be meaningless.

\subsection{Risk of bias assessment}

Detailed ratings for items within each component of the Newcastle-Ottawa scale are presented in Table 1 . Mean quality score was 5.45, and ranged from 3 to 8 on the 10-point Newcastle-Ottawa Scale indicating low quality in general. In particular, using the Newcastle-Ottawa Scale, no study was rated as having low risk of bias, three studies $(10.3 \%)$ as moderate risk, and 26 studies (89.7\%) were rated as having high risk of bias. Sample size justification and comparability between respondents and non-respondents characteristics were the most frequent bias since 


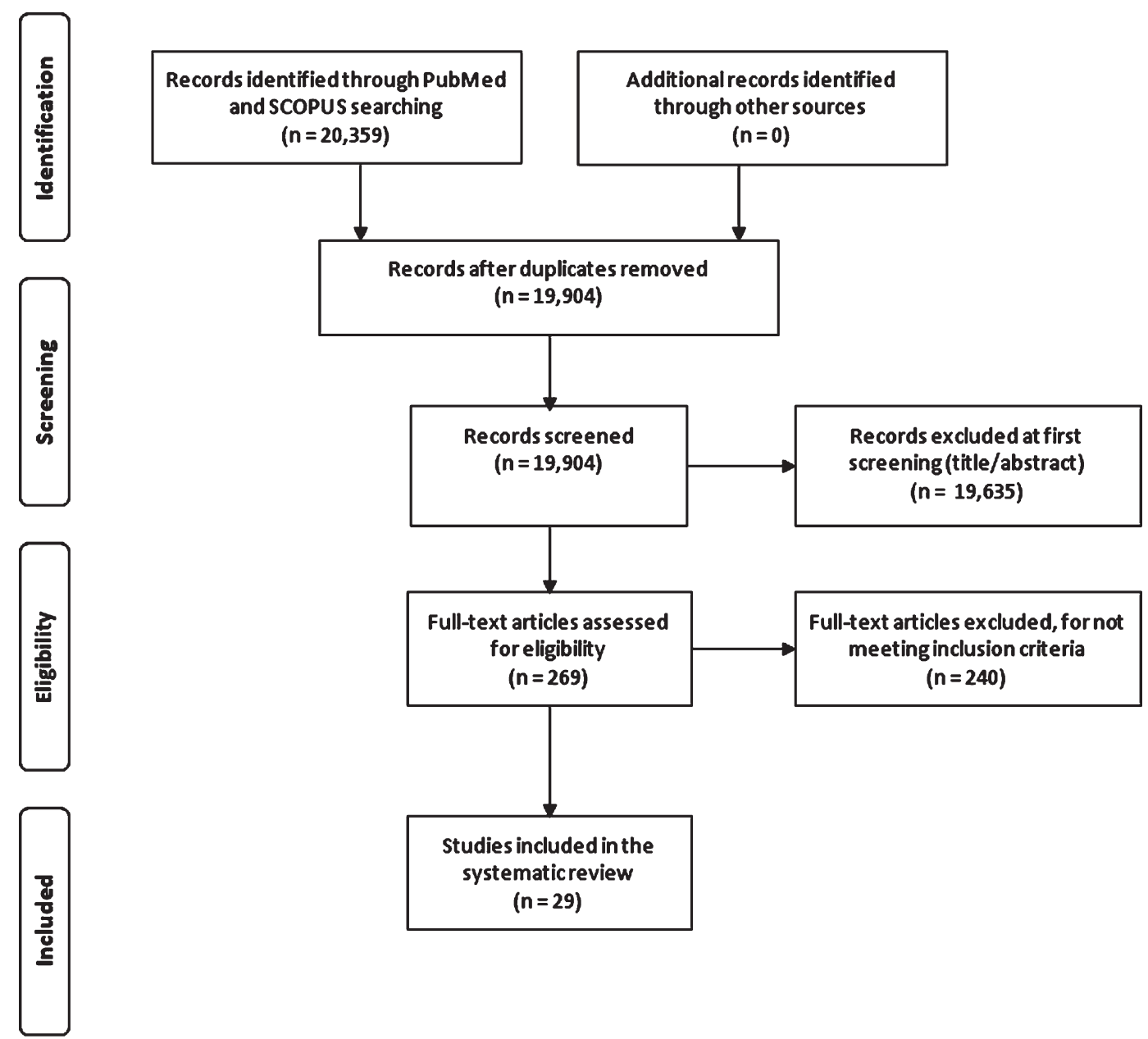

Adapted from Moher et al. (2009\}.

Fig. 1. Adapted from Moher et al. (2009).

only two [31, 58] and four studies [43, 52, 57, 66] respectively addressed these issues. Another common bias was the incomplete description of the statistical test since only eight studies $[21,31,41,43,45,50,52$, 53 ] described and presented appropriately the measures of effect, including confidence intervals and the probability level ( $p$ value). Nine studies $[22,58-65]$ did not eliminate confounders, while five studies [21, 47, 60-62] did not describe the sampling strategy. Risk factors and outcome were ascertained by means of self-reported questionnaires in all studies.

\subsection{Outcome}

Job-related stress was the outcome in 14 studies $[23,41,44,46,47,50,53,58,59,61-63,65,66]$, life stress was the outcome in 13 studies [21, 22, 31,
$42,43,45,51,54-57,60,64]$ while both job-related stress and life stress were the outcome in two studies $[49,52]$. Stress measurement was performed with a visual analogue scale in one study [52], with a dichotomous (yes/no) question about stress in another study [62] and with validated questionnaires in the other 27 studies. The most frequent questionnaires were the "General Health Questionnaire, GHQ" (three studies), the "Perceived Stress Scale, PSS" (two studies), the "Effort/Reward Imbalance" questionnaire (two studies), the "Brief Symptom Inventory, BSI" (two studies) and the "Spielberger Police Stress Survey" (two studies).

\subsection{Risk factors}

Due to high number and variability of stress risk factors, we decided to summarize them in the 
Table 1

Risk of bias assessment in studies included in the systematic review

\begin{tabular}{|c|c|c|c|c|c|c|c|c|c|}
\hline \multirow[t]{2}{*}{ Reference $^{a}$} & \multicolumn{4}{|c|}{$\begin{array}{c}\text { Selection } \\
\text { (maximum } 5 \text { stars) }\end{array}$} & \multirow{2}{*}{$\begin{array}{c}\begin{array}{c}\text { Comparability } \\
\text { (maximum } 2 \text { stars) }\end{array} \\
\text { Confounding } \\
\text { factors were } \\
\text { controlled }\end{array}$} & \multicolumn{2}{|c|}{$\begin{array}{l}\text { Outcome assessment } \\
\text { (maximum } 3 \text { stars) }\end{array}$} & \multirow{2}{*}{$\begin{array}{c}\text { Total quality } \\
\text { (maximum } \\
10 \text { stars) }\end{array}$} & \multirow[t]{2}{*}{$\begin{array}{l}\text { Overall } \\
\text { risk }\end{array}$} \\
\hline & $\begin{array}{l}\text { Representati- } \\
\text { veness of } \\
\text { the sample }\end{array}$ & $\begin{array}{l}\text { Sample } \\
\text { size }\end{array}$ & $\begin{array}{l}\text { Non- } \\
\text { respondents }\end{array}$ & $\begin{array}{l}\text { Ascertainment } \\
\text { of the } \\
\text { risk factor }\end{array}$ & & $\begin{array}{l}\text { Assessment } \\
\text { of the } \\
\text { outcome }\end{array}$ & $\begin{array}{l}\text { Statistical } \\
\text { test }\end{array}$ & & \\
\hline Tsai et al. (2018) & 效 & - & - & 为为 & 为为 & is & 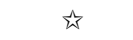 & 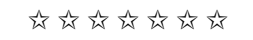 & High \\
\hline Duxbury \& Halinski (2017) & 站 & - & - & 战放 & 放 & 放 & - & 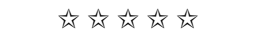 & High \\
\hline West et al. (2017) & 功 & - & - & 为为 & 为为 & 次 & 次 & 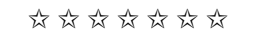 & High \\
\hline Griffin \& Sun (2017) & 头 & - & 必 & 为为 & 为为 & th & 功 & 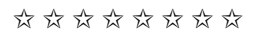 & Moderate \\
\hline Lambert et al. (2017) & 头 & - & - & $\Delta$ & 为为 & 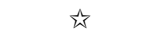 & - & 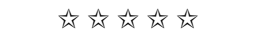 & High \\
\hline Nelson et al. (2016) & - & - & - & 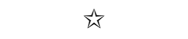 & 为论 & 次 & 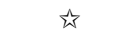 & 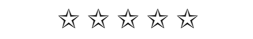 & High \\
\hline Luceño-Moreno et al. (2016) & 必 & $\sqrt{2}$ & - & 为为 & - & $\Delta$ & - & 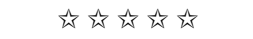 & High \\
\hline Maran et al. (2015) & - & - & - & 为为 & 为综 & $\Delta$ & - & 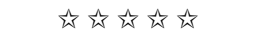 & High \\
\hline Seok et al. (2015) & $\dot{x}$ & - & - & 为为 & - & $\Delta$ & - & 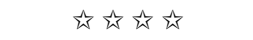 & High \\
\hline Lu et al. (2015) & 必 & - & - & 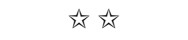 & - & 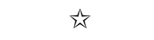 & - & 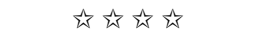 & High \\
\hline Ma et al. (2014) & $\sqrt{2}$ & - & - & 为放 & 为综 & $\Delta$ & - & 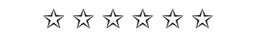 & High \\
\hline Masilamani et al. (2013) & 次 & $\lesssim$ & - & 弐方公 & 放放 & 氺 & 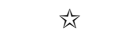 & 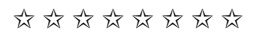 & Moderate \\
\hline Kaur et al. (2013) & - & - & - & 为放 & - & 办 & - & 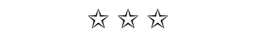 & High \\
\hline Garbarino et al. (2013) & th & - & 必 & 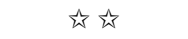 & 为放 & $\Delta$ & - & 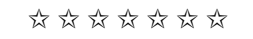 & High \\
\hline Selokar et al. (2011) & - & - & - & 为放 & - & 头 & - & 为为方出 & High \\
\hline Gerber et al. (2010) & 必 & - & - & $\sqrt{4}$ & 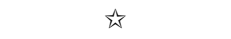 & $\Delta$ & - & 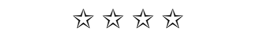 & High \\
\hline Žukauskas et al. (2009) & - & - & - & 象放 & - & 头 & - & 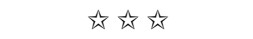 & High \\
\hline Gershon et al. (2009) & $\sqrt{3}$ & - & - & 为放 & 为放 & $\sqrt{3}$ & $\sqrt{2}$ & 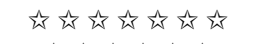 & High \\
\hline Berg et al. (2005) & 次 & - & - & 为为 & 象综 & tr & - & 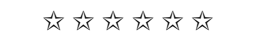 & High \\
\hline Collins \& Gibbs (2003) & 办 & - & - & 为为 & 为㑔 & 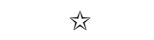 & - & 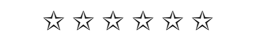 & High \\
\hline Deschamps et al. (2003) & 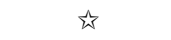 & - & 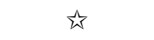 & 为为 & 为放 & 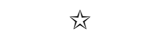 & 必 & 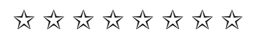 & Moderate \\
\hline Gershon et al. (2002) & 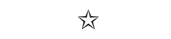 & - & - & 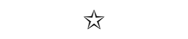 & 为放 & 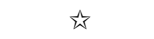 & 冰 & 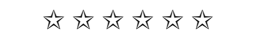 & High \\
\hline He et al. (2002) & 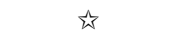 & - & - & 为放 & 放放 & 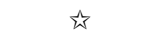 & - & 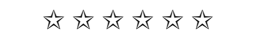 & High \\
\hline Zhao et al. (2002) & 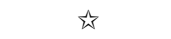 & - & - & 为放 & 为放 & 次 & - & 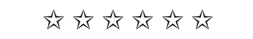 & High \\
\hline Patterson (2001) & 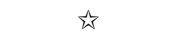 & - & - & 必为 & 为综 & 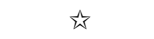 & - & 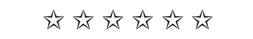 & High \\
\hline Brown et al. (1996) & 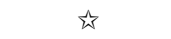 & - & - & 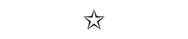 & - & 头 & - & 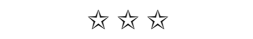 & High \\
\hline Violanti (1992) & 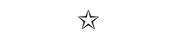 & - & 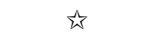 & 头㑔 & 为放 & 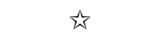 & - & 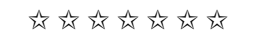 & High \\
\hline Brown \& Campbell (1990) & 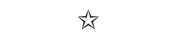 & - & - & 为为 & - & $\Delta$ & - & 放为公为 & High \\
\hline White et al. (1985) & 论 & - & - & 头放 & - & $\sqrt{2}$ & - & 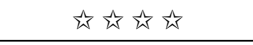 & High \\
\hline
\end{tabular}

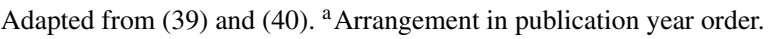


following categories to simplify the understanding of the review: demographic characteristics; job characteristics; lifestyle factors; coping strategies; personality traits. Measures of effect (coefficient b, correlation coefficient and odds ratio) and measures of precision ( $p$-value and 95\% confidence interval) are presented separately for each study in the Appendix to avoid repetition.

\subsection{Demographic characteristics}

Increased age was associated with stress [23], while married police officers experienced more stress versus singles/divorced [61]. Males and police officers who worked in districts with $>50,000$ inhabitants experienced more stress [23].

\subsection{Job characteristics}

Conflicting results were found regarding police rank, since two studies found that lower police rank increased stress $[58,64]$ and three studies found that higher police rank increased stress [23, 31, 41]. Moreover, increased years of experience increased [52] or decreased [65] stress.

Negative work-related conditions increase stress such as work-role overload [42], increased working hours [61], shift work [46, 49, 62], decreased job satisfaction [50, 59, 63] and on-duty injuries [45]. Other work stressors include work-family conflict [43, 44, 54], negative working environment [41, 54, 67], patrol assignment [43], burnout [65], bureaucracy [55], and self-estimation that salary is inappropriate regarding duties [31].

Four studies [50, 51, 53, 62] found that operational and organizational work factors increase stress. In particular, exposure to critical incidents (e.g. violence, crowd control, dealing with rape victims, using force, negative public opinion and hoax calls) increased stress [50, 53, 62]. Additionally, demands of work impinging on home, lack of support from senior officers, dealing with someone who is drunk, subject to a complaints investigator, being at risk of hepatitis or AIDS, not enough control over work, and urgent requests preventing planned work are stress risk factors [51]. Finally, poor cooperation, workplace discrimination and lack of organizational fairness are operational and organizational work factors that increase stress [50].

\subsection{Lifestyle factors}

Decreased physical exercise [22, 52, 65], lack of hobbies [52,65] and smoking [22] were considered to be stressors.

\subsection{Coping strategies}

Eleven studies [21, 23, 47, 50, 53, 54, 56, 57, 60, $63,65]$ found that negative and maladaptive coping strategies, such as self-distraction, denial, self-blame, lack of humour, lack of planning, lack of control and avoidance, increased stress.

\subsection{Personality traits}

Several negative personality traits such as neuroticism, psychoticism, introversion, and decreased resiliency were associated with stress [43, 60, 66]. Neuroticism involves anxiety, worrying, mood disorders, and negative feelings [68], psychoticism involves inappropriate emotional expression [69], while resiliency refers to positive personality traits, e.g. situation control and work commitment [70].

\section{Discussion}

To the best of our knowledge, this systematic literature review is the first that has been conducted to identify risk factors for stress among police officers. We have found evidence for the link between stress and a variety of demographic characteristics, job characteristics, lifestyle factors, coping strategies and personality traits. However, this evidence appears to be weak due to high risk of bias in the studies included in the review.

Regarding demographics, we found that increased age was associated with stress while married, and males experience more stress. Increased age is associated with tiredness and exposure to life and job-related stressors, while low marital quality and marital dissatisfaction can be a source of chronic stress resulting on decreased well-being [71], psychiatric disorders [72], and major depressive episodes [73].

We found that police officers who worked in large cities experienced more stress. Work in large cities may increase stress among police officers due to their frequent exposure in critical and extremely stressor incidents including among others murders, suicides, robberies, on-duty injuries, violence, crowd control, and dealing with rape victims [23]. These stressful 
work situations may predispose police officers to post-traumatic stress disorder since they often arrive first at the scene of suicides, murders, sexual abuses and traffic accidents. The risk for developing post-traumatic stress disorder is increased among professionals who are exposed to traumatic events, such as firefighters, emergency medical personnel and military veterans [74-76], and also among police officers especially for those dealing with seriously injured persons [77, 78]. Thus, appropriate interventions and management are required in order to raise the self-awareness of police officers regarding mental disorders and especially post-traumatic stress disorder. In addition to this, police officers in big cities may work under more difficult work-related conditions such as increased working hours, work-role overload and negative working environment. These difficult work-related conditions lead on decreased job satisfaction, work-family conflicts, burnout and decreased sleeping hours and leisure time.

Regarding job characteristics, we found that negative work-related conditions increase stress as well as operational and organizational work stressors. A negative work environment affects both mental and physical health resulting on stress-related disorders even on depression $[79,80]$. Police officer rank is a controversial issue without clear evidence about the way that is related with stress. Rank is usually associated with office work since higher rank officers tend to work in the office, while lower ranked officers who will spend more time away from the station on patrol. Out of office work is usually accompanied with exposure in critical and extremely stressor incidents increasing the risk for mental disorders such as stress, anxiety, depression and post-traumatic stress disorder as mentioned earlier [51, 62, 77, 78]. Office work is related with duties that increase stress such as more responsibilities, decision-making processes, and bureaucracy $[41,81]$. Higher ranking police officers take on more responsibility since they have to make important decisions usually under pressure. The more the police officers participate in decisionmaking processes, the more the stress and the strain they may experience.

With regards to lifestyle factors, decreased physical exercise and lack of hobbies considered to be stressors. Literature confirms this finding since physical exercise and especially aerobic exercise decreases stress, anxiety and depression, and protects a person from psychiatric disorders [82-87]. Physical exercise decreases stress by improving the function of metabolism, nervous and cardiovascular system
[88-90], and strengthening self-confidence and selfcontrol [91-93]. Physical exercise seems to be a promising cost-effective adjunctive treatment option for mood disorders since it could be easily disseminated and applied with minimal side effects [82]. Additionally, exercise improves both mental and physical health because of its broad-reaching effects. In particular, exercise is as effective as psychotherapy in the management of anxiety in patients with mood disorders and almost as effective as pharmacotherapy [82, 94, 95]. Personal training based on clinical and demographic characteristics of individuals could maximize exercise efficacy.

A number of studies in this review confirm that negative and maladaptive coping strategies increase stress. Coping strategies are cognitive and behavioral actions used to confront stressor events, and their choice depends mainly on personal experiences and attitudes [3, 57]. Positive coping strategies such as those focus on problem (e.g. planning, immediate response and support from others) help people to find their mental balance and adapt better in stressor events resulting on better stress management [57, 96]. On the contrary, negative and maladaptive coping strategies (e.g. self-distraction, denial, self-blame, lack of planning and lack of control) increase stress and affect negatively mental and physical health [53, 97]. Identification of stress risk factors is the first step to create and adopt the appropriate interventions, such as health promotion programs and counseling services, in order to decrease stress. In particular, health promotion programs should be targeted on the implementation of coping strategies and the improvement of lifestyle factors among police officers.

We found that negative personality traits and especially neuroticism and psychotism increase stress among police officers, a finding that is confirmed from systematic reviews in other populations [98, 99]. In these reviews, negative personality traits and neuroticism are associated with stress, depression and drugs abuse (REFS). Neuroticism involves anxiety, worrying, mood disorders, and negative feelings, with neurotic individuals experience more distress, symptoms, and pain [68]. Psychoticism involves inappropriate emotional expression, taking risks, and disregard for common sense resulting usually on antisocial behavior [69]. Police officers with neurotic and psychotic personality traits are more vulnerable to experience stress when deal with the challenging tasks of police job [60]. Similar, introversion is more likely to be seen in neurotic people [100], while there is a positive correlation between stress and 
neurotic and psychotic traits and a negative correlation between stress and extroversion [101]. Resilient individuals possess positive personality traits such as situation control, work commitment and challenge that increase self-confidence and growth and decrease stress [70].

Our review has several limitations. Firstly, all studies included in the review were cross-sectional. It is well-known that temporality of relationship between risk factors and outcome in cross-sectional studies creates uncertainty unless the risk factor is something fixed, such as gender. Cross-sectional studies cannot prove causality but help to generate more vigorous research hypotheses that should be tested with more valid studies such as cohort or randomized studies. Moreover, low quality of studies included in the review results on weak evidence for the link between risk factors and stress. Such a bias is inherent in reviews with studies with high risk of bias and could be decreased only by designing and conducting more reliable and valid studies. Although the great number of studies that have been conducted in the field, there is a need for more well-designed and rigorous studies with less bias than previous studies. Even though evidence from this review appears to be weak due to high risk of bias in existing studies, the existence of stress factors among police officers is a reality. Moreover, the different ways that studies have used to measure both risk factors and stress may have affected the review findings and require a careful interpretation. For example, the definition of "stress" is challenging and its objective measurement is quite difficult even impossible due to individual perceptions and different self-reported questionnaires that used in studies.

\section{Conclusion}

There is a need for health surveillance and a continuous assessment of mental health of police personnel to promote health and maintain well-being. The early identification of police officers at higher risk and the appropriate screening for mental health disorders such as depression, anxiety disorders, post-traumatic stress disorder, suicides thoughts and behaviors is crucial to prevent disease and promote quality of life.

\section{Conflict of interest}

None to report.

\section{Supplementary material}

The Appendix is available from https://dx.doi.org/ 10.3233/WOR-213455.

\section{References}

[1] Butler G. Definitions of stress. Occas Pap R Coll Gen Pract. 1993;61:1-5.

[2] Monroe SM. Modern approaches to conceptualizing and measuring human life stress. Annu Rev Clin Psychol. 2008;4:33-52.

[3] Lazarus RS FS. Stress, appraisal, and coping. New York: Springer-Verlag; 1984.

[4] Weiner H. Perturbing the organism: the biology of stressful experience. Chicago: University Chicago Press; 1992.

[5] Cannizzaro E, Ramaci T, Cirrincione L, Plescia F. WorkRelated Stress, Physio-Pathological Mechanisms, and the Influence of Environmental Genetic Factors. International Journal of Environmental Research and Public Health. 2019;16(20).

[6] Decker A, Askar H, Tattan M, Taichman R, Wang HL. The assessment of stress, depression, and inflammation as a collective risk factor for periodontal diseases: a systematic review. Clin Oral Investig. 2019.

[7] Sui H, Sun N, Zhan L, Lu X, Chen T, Mao X. Association between Work-Related Stress and Risk for Type 2 Diabetes: A Systematic Review and MetaAnalysis of Prospective Cohort Studies. PloS one. 2016;11(8):e0159978.

[8] Backé EM SA, Latza U, Rossnagel K, Schumann B. The role of psychosocial stress at work for the development of cardiovascular diseases: a systematic review. Arch Occup Environ Health. 2012;85(1):67-79.

[9] Hassard J, Teoh KRH, Visockaite G, Dewe P, Cox T. The cost of work-related stress to society: A systematic review. Journal of Occupational Health Psychology. 2018;23(1):117.

[10] Guthrie R, Ciccarelli M, Babic A. Work-related stress in Australia: The effects of legislative interventions and the cost of treatment. Int J Law Psychiatry. 2010;33(2):10115 .

[11] International L, Organization. Workplace stress: A collective challenge. Switzerland: International Labour Office; 2016.

[12] Cox TG A, Rial-González E. Research on work-related stress. Luxembourg: European Agency for Safety and Health at Work; 2000.

[13] Fisher S. Life change, personal control and disease. South African Journal of Psychology. 1996;26(1):16-22.

[14] Dohrenwend BS, Krasnoff L, Askenasy AR, Dohrenwend BP. The Psychiatric Epidemiology Research Interview Life Events Scale. In: Goldberg L, Breznitz S, editors. Handbook of Stress: Theoretical and Clinical Aspects. New York: Free Press; 1988.

[15] Derogatis L, Savitz K. The SCL-90-R, Brief Symptom Inventory and matching clinical rating scales. In: M M, editor. The use of psychological testing for treatment, planning and outcomes assessment. Mahwah, NJ: Lawrence Erlbaum; 1999.

[16] Leuner B, Shors T. Stress, anxiety, and dendritic spines: what are the connections? Neuroscience. 2013;251:10819. 
[17] Stanley IH, Hom MA, Joiner TE. A systematic review of suicidal thoughts and behaviors among police officers, firefighters, EMTs, and paramedics. Clinical Psychology Review. 2016;44:25-44.

[18] Skogstad M, Skorstad M, Lie A, Conradi HS, Heir T, Weisæth L. Work-related post-traumatic stress disorder. Occupational Medicine. 2013;63(3):175-82.

[19] Stuart H. Suicidality among police. Current Opinion in Psychiatry. 2008;21(5):505-9.

[20] Houdmont J, Randall R. Working hours and common mental disorders in English police officers. Occupational Medicine. 2016;66(9):713-8.

[21] Nelson KV, Smith AP. Occupational stress, coping and mental health in Jamaican police officers. Occupational Medicine (Oxford, England). 2016;66(6):488-91.

[22] Seok JM, Cho JH, Jeon WJ, Ahn JO. Risk factors for fatigue and stress among Korean police officers. Journal of Physical Therapy Science. 2015;27(5):1401-5.

[23] Berg AM, Hem E, Lau B, Haseth K, Ekeberg O. Stress in the Norwegian police service. Occupational Medicine (Oxford, England). 2005;55(2):113-20.

[24] Alexopoulos EC, Palatsidi V, Tigani X, Darviri C. Exploring stress levels, job satisfaction, and quality of life in a sample of police officers in Greece. Safety and Health at Work. 2014;5(4):210-5.

[25] Fekedulegn D, Burchfiel CM, Hartley TA, Andrew ME, Charles LE, Tinney-Zara CA, et al. Shiftwork and sickness absence among police officers: the BCOPS study. Chronobiology International. 2013;30(7):930-41.

[26] Fox J, Desai MM, Britten K, Lucas G, Luneau R, Rosenthal MS. Mental-health conditions, barriers to care, and productivity loss among officers in an urban police department. Connecticut Medicine. 2012;76(9):525-31.

[27] Körlin J, Alexanderson K, Svedberg P. Sickness absence among women and men in the police: A systematic literature review. Scandinavian Journal of Public Health. 2009;37(3):310-9.

[28] Lipp MEN. Stress and quality of life of senior Brazilian police officers. Spanish Journal of Psychology. 2009;12(2):593-603.

[29] Magnavita N, Capitanelli I, Garbarino S, Pira E. Workrelated stress as a cardiovascular risk factor in police officers: a systematic review of evidence. International Archives of Occupational and Environmental Health. 2018;91(4):377-89.

[30] Garbarino S, Magnavita N. Work Stress and Metabolic Syndrome in Police Officers. A Prospective Study. PloS One. 2015;10(12):e0144318.

[31] Masilamani R, Bulgiba A, Chinna K, Darus A, Isahak M, Kandiben S, et al. Prevalence and associated factors of stress in the Malaysian Police Force. Preventive Medicine. 2013;57(Suppl):S57-9.

[32] Hartley TA, Burchfiel CM, Fekedulegn D, Andrew ME, Knox SS, Violanti JM. Associations between police officer stress and the metabolic syndrome. International Journal of Emergency Mental Health. 2011;13(4): 243-56.

[33] Charles LE, Slaven JE, Mnatsakanova A, Ma C, Violanti JM, Fekedulegn D, et al. Association of perceived stress with sleep duration and sleep quality in police officers. International Journal of Emergency Mental Health. 2011;13(4):229-41.

[34] Sterud T, Hem E, Ekeberg O, Lau B. Occupational stress and alcohol use: a study of two nationwide samples of operational police and ambulance, personnel in Norway.
Journal of Studies on Alcohol and Drugs. 2007;68(6):896904.

[35] Smith DR, Devine S, Leggat PA, Ishitake T. Alcohol and tobacco consumption among police officers. The Kurume Medical Journal. 2005;52(1-2):63-5.

[36] Moher D, Liberati A, Tetzlaff J, Altman D, Group P. Preferred reporting items for systematic reviews and meta-analyses: the PRISMA statement. PLoS Medicine. 2009;6(7):e1000097.

[37] Milner K, Cosme S. The PICO Game: An Innovative Strategy for Teaching Step 1 in Evidence-Based Practice. Worldviews Evid Based Nurs. 2017;14(6):514-6.

[38] Twa M. Evidence-Based Clinical Practice: Asking Focused Questions (PICO). Optom Vis Sci. 2016;93(10):1187-8.

[39] Modesti P, Reboldi G, Cappuccio F, Agyemang C, Remuzzi G, Rapi S, et al. Panethnic Differences in Blood Pressure in Europe: A Systematic Review and MetaAnalysis. PloS One. 2016;11(1):e0147601.

[40] Herzog R, Álvarez-Pasquin M, Díaz C, Del Barrio J, Estrada J, Gil Á. Are healthcare workers' intentions to vaccinate related to their knowledge, beliefs and attitudes? A systematic review. BMC Public Health. 2013;13:154.

[41] Tsai LCF, Nolasco CARI, Vaughn MS. Modeling job stress among police officers: interplay of work environment, counseling support, and family discussion with co-workers. Police Practice and Research. 2018;19(3):253-69.

[42] Duxbury L, Halinski M. It's not all about guns and gangs: role overload as a source of stress for male and female police officers. Policing and Society. 2017.

[43] Griffin J, Sun I. Do Work-Family Conflict and Resiliency Mediate Police Stress and Burnout: a Study of State Police Officers. American Journal of Criminal Justice. 2017;43:354-70.

[44] Lambert EG, Qureshi H, Frank J, Keena LD, Hogan NL. The relationship of work-family conflict with job stress among Indian police officers: a research note. Police Practice and Research. 2017;18(1):37-48.

[45] West C, Fekedulegn D, Andrew M, Burchfiel CM, Harlow $\mathrm{S}$, Bingham CR, et al. On-Duty Nonfatal Injury that Lead to Work Absences among Police Officers and Level of Perceived Stress. Journal of Occupational and Environmental Medicine. 2017;59(11):1084-8.

[46] Ma CC, Andrew ME, Fekedulegn D, Gu JK, Hartley TA, Charles LE, et al. Shift work and occupational stress in police officers. Safety and Health at Work. 2015;6(1):25-9.

[47] Maran A, Varetto A, Zedda M, Ieraci V. Occupational stress, anxiety and coping strategies in police officers. Occupational Medicine. 2015;65(6):466-73.

[48] Garbarino S, Cuomo G, Chiorri C, Magnavita N. Association of work-related stress with mental health problems in a special police force unit. BMJ Open. 2013;3(7).

[49] Gerber M, Hartmann T, Brand S, Holsboer-Trachsler E, Pühse U. The relationship between shift work, perceived stress, sleep and health in Swiss police officers. Journal of Criminal Justice. 2010;38(6):1167-75.

[50] Gershon R, Barocas B, Canton A, Xianbin L, Vlahov D. Mental, physical, and behavioral outcomes associated with perceived work stress in police officers. Criminal Justice and Behavior. 2009;36(3):275-89.

[51] Collins PA, Gibbs AC. Stress in police officers: a study of the origins, prevalence and severity of stress-related symptoms within a county police force. Occupational Medicine (Oxford, England). 2003;53(4):256-64. 
[52] Deschamps F, Paganon-Badinier I, Marchand AC, Merle C. Sources and assessment of occupational stress in the police. Journal of Occupational Health. 2003;45(6):35864.

[53] Gershon R, Lin S, Li X. Work stress in aging police officers. Journal of Occupational and Environmental Medicine. 2002;44(2):160-7.

[54] He N, Zhao J, Archbold CA. Gender and police stress: The convergent and divergent impact of work environment, work-family conflict, and stress coping mechanisms of female and male police officers. Policing. 2002;25(4):687708.

[55] Zhao J, He N, Lovrich N. Predicting Five Dimensions of Police Officer Stress: Looking More Deeply Into Organizational Settings for Sources of Police Stress. Police Quarterly. 2002;5(1):43-62.

[56] Patterson MC, Poole AD, Trew KJ, Harkin N. The psychological and physical health of police officers retired recently from the Royal Ulster Constabulary. Irish Journal of Psychology. 2001;22(1):1-27.

[57] Violanti JM. Coping strategies among police recruits in a high-stress training environment. The Journal of Social Psychology. 1992;132(6):717-29.

[58] Luceño-Moreno L, Garcia-Albuerne Y, Talavera-Velasco B, Martin-Garcia J. Stress in Spanish police force depending on occupational rank, sex, age and work-shift. Psicothema. 2016;28(4):389-93.

[59] Lu L, Liu L, Sui G, Wang L. The Associations of Job Stress and Organizational Identification with Job Satisfaction among Chinese Police Officers: The Mediating Role of Psychological Capital. International Journal of Environmental Research and Public Health. 2015;12(12):15088-99.

[60] Kaur R, Chodagiri VK, Reddi NK. A psychological study of stress, personality and coping in police personnel. Indian Journal of Psychological Medicine. 2013;35(2):141-7.

[61] Selokar D, Nimbarte S, Ahana S, Gaidhane A, Wagh V. Occupational stress among police personnel of Wardha city, India. The Australasian Medical Journal. 2011;4(3):114-7.

[62] Žukauskas G, Burba B, Rukšenas O, Grigaliuniene V, Mitchell JT. A study of stress affecting police officers in Lithuania. International Journal of Emergency Mental Health. 2009;11(4):205-14

[63] Brown J, Cooper C, B. K. Occupational stress among senior police officers. Br J Psychol. 1996;87(1):31-41.

[64] Brown JM, Campbell EA. Sources of occupational stress in the police. Work and Stress. 1990;4(4):305-18.

[65] White JW, Lawrence PS, Grubb TD, Biggerstaff C. Factors of Stress among Police Officers. Criminal Justice and Behavior. 1985;12(1):111-28.

[66] Garbarino S, Chiorri C, Magnavita N. Personality traits of the Five-Factor Model are associated with workrelated stress in special force police officers. International Archives of Occupational and Environmental Health. 2013;87(3):295-306.

[67] Chen HC, Chou FHC, Chen MC, Su SF, Wang SY, Feng WW, et al. A survey of quality of life and depression for police officers in Kaohsiung, Taiwan. Quality of Life Research. 2006;15(5):925-32.

[68] Friedman HS. Neuroticism and health as individuals age. Personal Disord. 2019;10(1):25-32.

[69] Eysenck HJ. Creativity and personality: Suggestions for a theory. Psychological Inquiry. 1993;4(147-178).
[70] Miller L. Stress and resilience in law enforcement training and practice. International Journal of Emergency Mental Health. 2008;10(2):109-24.

[71] Coyne J, DeLongis A. Going beyond social support: the role of social relationships in adaptation. Journal of Consulting and Clinical Psychology. 1986;54(4):454-60.

[72] Whisman M, Bruce M. Marital dissatisfaction and incidence of major depressive episode in a community sample. Journal of Abnormal Psychology. 1999;108(4):674-8.

[73] Teo A, Choi H, Valenstein M. Social relationships and depression: Ten-year follow-up from a nationally representative study. PloS One. 2013;8(4):e62396.

[74] Alexander DA, Klein S. Ambulance personnel and critical incidents: impact of accident and emergency work on mental health and emotional well-being. The British Journal of Psychiatry : The Journal of Mental Science. 2001;178(1):76-81.

[75] Galea S, Ahern J, Resnick H, Kilpatrick D, Bucuvalas M, Gold J, et al. Psychological sequelae of the September 11 terrorist attacks in New York City. The New England Journal of Medicine. 2002;346(13):982-7.

[76] Wolfe J, Schnurr PP, Brown PJ, Furey J. Posttraumatic stress disorder and war-zone exposure as correlates of perceived health in female Vietnam War veterans. Journal of Consulting and Clinical Psychology. 1994;62(6): 1235-40.

[77] Hartley TA, Violanti JM, Sarkisian K, Andrew ME, Burchfiel CM. PTSD symptoms among police officers: associations with frequency, recency, and types of traumatic events. International Journal of Emergency Mental Health. 2013;15(4):241-53.

[78] Lee JK, Choi HG, Kim JY, Nam J, Kang HT, Koh SB, et al. Self-resilience as a protective factor against development of post-traumatic stress disorder symptoms in police officers. Annals of Occupational and Environmental Medicine. 2016;28.

[79] Giorgi G, Arcangeli G, Perminiene M, Lorini C, ArizaMontes A, Fiz-Perez J, et al. Work-Related Stress in the Banking Sector: A Review of Incidence, Correlated Factors, and Major Consequences. Front Psychol. 2017;8:2166.

[80] Nieuwenhuijsen K, Bruinvels D, Frings-Dresen M. Psychosocial work environment and stress-related disorders, a systematic review. Occupational Medicine (Oxford, England). 2010;60(4):277-86.

[81] Lord VB. An impact of community policing: Reported stressors, social support, and strain among police officers in a changing police department. Journal of Criminal Justice. 1996;24(6):503-22.

[82] Hearing CM, Chang WC, Szuhany KL, Deckersbach T, Nierenberg AA, Sylvia LG. Physical Exercise for Treatment of Mood Disorders: A Critical Review. Current Behavioral Neuroscience Reports. 2016;3(4):350-9.

[83] Anderson E, Shivakumar G. Effects of exercise and physical activity on anxiety. Front Psychiatry. 2013;4:27.

[84] van Minnen A, Hendriks L, Olff M. When do trauma experts choose exposure therapy for PTSD patients? A controlled study of therapist and patient factors. Behaviour Research and Therapy. 2010;48(4):312-20.

[85] Broman-Fulks JJ, Storey KM. Evaluation of a brief aerobic exercise intervention for high anxiety sensitivity. Anxiety, Stress, and Coping. 2008;21(2):117-28.

[86] Smits JA, Berry AC, Rosenfield D, Powers MB, Behar E, Otto MW. Reducing anxiety sensitivity with exercise. Depress Anxiety. 2008;25(8):689-99. 
[87] Strőhle A, Hofler M, Pfister H, Muller AG, Hoyer J, Wittchen HU, et al. Physical activity and prevalence and incidence of mental disorders in adolescents and young adults. Psychological Medicine. 2007;37(11):1657-66.

[88] Halverstadt A, Phares DA, Wilund KR, Goldberg AP, Hagberg JM. Endurance exercise training raises high-density lipoprotein cholesterol and lowers small low-density lipoprotein and very low-density lipoprotein independent of body fat phenotypes in older men and women. Metabolism. 2007;56(4):444-50.

[89] Rimmele U, Zellweger BC, Marti B, Seiler R, Mohiyeddini C, Ehlert U, et al. Trained men show lower cortisol, heart rate and psychological responses to psychosocial stress compared with untrained men. Psychoneuroendocrinology. 2007;32(6):627-35.

[90] Jackson EM, Dishman RK. Cardiorespiratory fitness and laboratory stress: a meta-regression analysis. Psychophysiology. 2006;43(1):57-72.

[91] Bodin T, Martinsen E. Mood and self-efficacy during acute exercise in clinical depression. A randomized, controlled study. J Sport Exerc Psychol. 2004;26(4):623-33.

[92] Katula JA, Blissmer BJ, McAuley E. Exercise intensity and self-efficacy effects on anxiety reduction in healthy, older adults. J Behav Med. 1999;22(3):233-47.

[93] Petruzzello SJ, Landers DM, Hatfield BD, Kubitz KA, Salazar W. A meta-analysis on the anxiety-reducing effects of acute and chronic exercise. Outcomes and mechanisms. Sports Med. 1991;11(3):143-82.

[94] Merom D, Phongsavan P, Wagner R, Chey T, Marnane C, Steel Z, et al. Promoting walking as an adjunct intervention to group cognitive behavioral therapy for anxiety disorders-a pilot group randomized trial. Journal of Anxiety Disorders. 2008;22(6):959-68.

[95] Broocks A, Bandelow B, Pekrun G, George A, Meyer $\mathrm{T}$, Bartmann U, et al. Comparison of aerobic exercise, clomipramine, and placebo in the treatment of panic disorder. The American Journal of Psychiatry. 1998;155(5):603-9.

[96] Geetha P, Subbakrishna D, Channabasavanna S. Subjective well being among police personnel. Indian Journal of Psychiatry. 1998;40:172-9.
[97] Johnson J, Hall E. Job strain, workplace social support and cardiovascular disease: a cross sectional study of a random sample of the Swedish working population. American Journal of Public Health. 1988;78(10):1336-42.

[98] Jaksǐć N, Brajković L, Ivezić E, Topić R, Jakovljevíc M. The role of personality traits in posttraumatic stress disorder (PTSD). Psychiatria Danubina. 2012;24(3):256-66.

[99] Kotov R, Gamez W, Schmidt F, Watson D. Linking "big" personality traits to anxiety, depressive, and substance use disorders: a meta-analysis. Psychol Bull. 2010;136(5):768-821.

[100] Francis LJ, Quigley CF, Robbins M, Lewis CA. The General Health Questionnaire and Eysenck's threedimensional model of personality. Psychological Reports. 2005;97(1):288-90.

[101] Fontana D, Abouserie R. Stress levels, gender and personality factors in teachers. Br J Educ Psychol. 1993;63 (Pt 2):261-70.

[102] Cohen S, Kamarck T, Mermelstein R. A global measure of perceived stress. J Health Soc Behav. 1983;24(4):385-96.

[103] Carlson D, Kacmar K, L W. Construction and initial validation of a multidimensional measure of work-family conflict. Journal of Vocational Behavior. 2000;56(2):24976.

[104] Crank JP, Regoli R, Hewitt JD, Culbertson RG. Institutional and organizational antecedents of role stress, work alienation, and anomie among police executives. Criminal Justice and Behavior. 1995;22(2):152-71.

[105] Beehr TA, Johnson LB, Nieva R. Occupational stress: Coping of police and their spouses. Journal of Organizational Behavior. 1995;16(1):3-25.

[106] Billings AG, Moos RH. The role of coping responses and social resources in attenuating the stress of life events. J Behav Med. 1981;4(2):139-57.

[107] Patterson G. Development of a law enforcement stress and coping questionnaire. Psychological Reports. 2002;90(3 PART 1):789-99.

[108] Maslach C. Stress and coping. Berkeley: University of California; 1977. 
Appendix

Summary of studies examining risk factors for stress among police officer

\begin{tabular}{|c|c|c|c|c|c|c|c|c|}
\hline Reference $^{\mathrm{a}}$ & Country & $\begin{array}{l}\text { Study } \\
\text { design }\end{array}$ & $\begin{array}{l}\text { Year of } \\
\text { data col- } \\
\text { lection }\end{array}$ & $\begin{array}{l}\text { Number of } \\
\text { police } \\
\text { officers } \\
\text { (percentage } \\
\text { of males, } \\
\text { mean age) }\end{array}$ & $\begin{array}{l}\text { Risk factors }{ }^{b} \\
\text { (question- } \\
\text { naire) }\end{array}$ & $\begin{array}{l}\text { Outcome } \\
\text { (questionnaire) }\end{array}$ & $\begin{array}{l}\text { Level of } \\
\text { analysis }^{c}\end{array}$ & Main results \\
\hline $\begin{array}{l}\text { Tsai et al. } \\
\text { (2018) }\end{array}$ & USA & $\begin{array}{l}\text { Cross- } \\
\text { sectional }\end{array}$ & 1995 & $\begin{array}{l}594(86.7 \%, \\
36.1 \text { years })\end{array}$ & $\begin{array}{l}\text { Demographic } \\
\text { characteris- } \\
\text { tics; job } \\
\text { characteristics }\end{array}$ & $\begin{array}{l}\text { Job stress (a latent } \\
\text { construct } \\
\text { consisting of } \\
\text { overall stress, } \\
\text { job stress and } \\
\text { burnout) }\end{array}$ & $\begin{array}{l}\text { Multivariate } \\
\quad \text { (Structural } \\
\text { equation } \\
\text { modeling) }\end{array}$ & $\begin{array}{l}\text { Higher police rank } \\
\text { (coefficient } \mathrm{b}=0.14 \text {, } \\
p<0.05 \text { ) and negative } \\
\text { working environment } \\
\text { (coefficient } \mathrm{b}=0.74, \\
p<0.05 \text { ) were associated } \\
\text { with stress }\end{array}$ \\
\hline $\begin{array}{c}\text { Duxbury \& } \\
\text { Halinski } \\
\text { (2017) }\end{array}$ & Canada & $\begin{array}{l}\text { Cross- } \\
\text { sectional }\end{array}$ & $\begin{array}{r}2011- \\
2012\end{array}$ & $\begin{array}{r}1469(79.6 \%, \\
40.9 \text { years })\end{array}$ & $\begin{array}{l}\text { Job } \\
\text { characteristics }\end{array}$ & $\begin{array}{l}\text { Life stress (10 } \\
\text { items measure) } \\
(102)\end{array}$ & $\begin{array}{l}\text { Multivariate } \\
\quad \text { (Structural } \\
\text { equation } \\
\text { modeling) }\end{array}$ & $\begin{array}{l}\text { Work-role overload was } \\
\text { associated with stress } \\
\text { (coefficient } \mathrm{b}=0.316 \\
p<0.001 \text { for males and } \\
\text { coefficient } \mathrm{b}=0.225 \\
p<0.001 \text { for females) }\end{array}$ \\
\hline $\begin{array}{l}\text { West et al. } \\
\text { (2017) }\end{array}$ & USA & $\begin{array}{l}\text { Cross- } \\
\text { sectional }\end{array}$ & $\begin{array}{r}2004- \\
2009\end{array}$ & $\begin{array}{l}422(74 \%, 43 \\
\text { years })\end{array}$ & $\begin{array}{l}\text { On-duty injury } \\
\text { (payroll work } \\
\text { history data) }\end{array}$ & $\begin{array}{l}\text { Life stress } \\
\text { (Perceived } \\
\text { Stress Scale, } \\
\text { PSS) }\end{array}$ & $\begin{array}{l}\text { Multivariate } \\
\text { linear } \\
\text { regression }\end{array}$ & $\begin{array}{l}\text { Increased on-duty injury } \\
\text { count was associated with } \\
\text { stress }(p=.025)\end{array}$ \\
\hline $\begin{array}{l}\text { Griffin \& Sun } \\
\text { (2017) }\end{array}$ & USA & $\begin{array}{l}\text { Cross- } \\
\text { sectional }\end{array}$ & 2011 & $\begin{array}{l}138(87 \% \\
\mathrm{NM})\end{array}$ & $\begin{array}{l}\text { Demographic } \\
\text { characteris- } \\
\text { tics; job } \\
\text { characteris- } \\
\text { tics; lifestyle } \\
\text { factors }\end{array}$ & $\begin{array}{l}\text { Life stress } \\
\text { (Perceived } \\
\text { Stress Scale, } \\
\text { PSS) }\end{array}$ & $\begin{array}{l}\text { Multivariate } \\
\text { linear } \\
\text { regression }\end{array}$ & $\begin{array}{l}\text { Patrol assignment } \\
\quad(\text { coefficient } \mathrm{b}=-0.17, \\
p<0.05), \text { work-family } \\
\text { conflict (coefficient } \\
\mathrm{b}=0.32, p<0.001 \text { ) and } \\
\text { decreased resiliency } \\
(\text { coefficient } \mathrm{b}=-0.26, \\
p<0.05) \text { were associated } \\
\text { with stress }\end{array}$ \\
\hline $\begin{array}{l}\text { Lambert et al. } \\
\text { (2017) }\end{array}$ & India & $\begin{array}{l}\text { Cross- } \\
\text { sectional }\end{array}$ & 2016 & $\begin{array}{l}827(88 \%, \\
36.5 \text { years })\end{array}$ & $\begin{array}{l}\text { Work-family } \\
\text { conflict (18 } \\
\text { items } \\
\text { measure) } \\
(103)\end{array}$ & $\begin{array}{c}\text { Job stress (6 items } \\
\text { measure) }(104)\end{array}$ & $\begin{array}{l}\text { Multivariate } \\
\text { linear } \\
\text { regression }\end{array}$ & $\begin{array}{l}\text { Work-family conflict } \\
\text { (coefficient } \mathrm{b}=0.25, \\
p<0.001 \text { for strain-based } \\
\text { scale; coefficient } \mathrm{b}=0.07 \text {, } \\
p<0.05 \text { for } \\
\text { behavior-based scale; } \\
\text { coefficient } \mathrm{b}=0.17, \\
p<0.01 \text { for family-based } \\
\text { scale) was associated } \\
\text { with stress }\end{array}$ \\
\hline
\end{tabular}




\begin{tabular}{|c|c|c|c|c|c|c|c|c|}
\hline $\begin{array}{l}\text { Nelson et al. } \\
\text { (2016) }\end{array}$ & Jamaica & $\begin{array}{l}\text { Cross- } \\
\text { sectional }\end{array}$ & 2016 & $\begin{array}{l}134(63 \%, 32 \\
\text { years) }\end{array}$ & $\begin{array}{l}\text { Demographic } \\
\text { characteris- } \\
\text { tics; job } \\
\text { characteris- } \\
\text { tics; coping } \\
\text { strategies } \\
\text { (NA) }\end{array}$ & $\begin{array}{l}\text { Life stress (items } \\
\text { from the } \\
\text { Well-being } \\
\text { Process } \\
\text { Questionnaire, } \\
\text { WPQ) }\end{array}$ & $\begin{array}{l}\text { Multivariate } \\
\text { linear } \\
\text { regression }\end{array}$ & $\begin{array}{l}\text { Negative work environment } \\
\text { (coefficient } \mathrm{b}=0.23, \\
p<0.001 \text { ) and coping } \\
\text { strategy focus on emotion } \\
\text { (coefficient } \mathrm{b}=0.43, \\
p<0.001 \text { ) were } \\
\text { associated with stress }\end{array}$ \\
\hline $\begin{array}{l}\text { Luceño- } \\
\text { Moreno et } \\
\text { al. (2016) }\end{array}$ & Spain & $\begin{array}{l}\text { Cross- } \\
\text { sectional }\end{array}$ & 2016 & $\begin{array}{l}565(87.4 \%, \\
39.7 \text { years })\end{array}$ & $\begin{array}{l}\text { Demographic } \\
\text { characteris- } \\
\text { tics; job } \\
\text { characteristics }\end{array}$ & $\begin{array}{l}\text { Job stress } \\
\quad \text { (DECORE) }\end{array}$ & Univariate & $\begin{array}{l}\text { Lower police rank was } \\
\text { associated with stress } \\
(p<0.01)\end{array}$ \\
\hline $\begin{array}{l}\text { Maran et al. } \\
\quad(2015)\end{array}$ & Italy & $\begin{array}{l}\text { Cross- } \\
\text { sectional }\end{array}$ & 2015 & $\begin{array}{l}617(58 \% \\
\mathrm{NM})\end{array}$ & $\begin{array}{l}\text { Demographic } \\
\text { characteris- } \\
\text { tics; job } \\
\text { characteris- } \\
\text { tics; coping } \\
\text { strategies } \\
\text { (Brief Cope) }\end{array}$ & $\begin{array}{l}\text { Job stress } \\
\text { (Operational } \\
\text { Police Stress } \\
\text { Questionnaire, } \\
\text { PSQ-Op; } \\
\text { Organizational } \\
\text { Police Stress } \\
\text { Questionnaire, } \\
\text { PSQ-Org) }\end{array}$ & $\begin{array}{l}\text { Multivariate } \\
\text { linear } \\
\text { regression }\end{array}$ & $\begin{array}{l}\text { Self-distraction }(p<0.01), \\
\text { denial }(p<0.05), \\
\text { self-blame }(p<0.01), \\
\text { lack of humour }(p<0.01) \\
\text { and lack of planning } \\
(p<0.05) \text { were associated } \\
\text { with stress }\end{array}$ \\
\hline $\begin{array}{r}\text { Seoketal. } \\
\text { (2015) }\end{array}$ & $\begin{array}{l}\text { South } \\
\text { Korea }\end{array}$ & $\begin{array}{l}\text { Cross- } \\
\text { sectional }\end{array}$ & 2013 & $\begin{array}{l}353(100 \% \\
\quad \mathrm{NM})\end{array}$ & $\begin{array}{l}\text { Demographic } \\
\text { characteris- } \\
\text { tics; job } \\
\text { characteris- } \\
\text { tics; life style } \\
\text { factors }\end{array}$ & $\begin{array}{l}\text { Life stress } \\
\text { (Psychosocial } \\
\text { Well-being } \\
\text { Index Short } \\
\text { form, PWI-SF) }\end{array}$ & Univariate & $\begin{array}{l}\text { Smoking, decreased } \\
\text { physical exercise and } \\
\text { chronic disease were } \\
\text { associated with stress } \\
(p<0.05 \text { in all cases })\end{array}$ \\
\hline $\begin{array}{l}\text { Lu et al. } \\
\quad(2015)\end{array}$ & China & $\begin{array}{l}\text { Cross- } \\
\text { sectional }\end{array}$ & 2014 & $\begin{array}{l}2226(84.6 \% \\
\text { NM) }\end{array}$ & $\begin{array}{l}\text { Job satisfaction } \\
\text { (Minnesota } \\
\text { Satisfaction } \\
\text { Questionnaire, } \\
\text { MSQ) }\end{array}$ & $\begin{array}{l}\text { Job stress } \\
\text { (Siegrist's } \\
\text { effort-reward- } \\
\text { imbalance, } \\
\text { ERI) }\end{array}$ & Univariate & $\begin{array}{l}\text { Decreased job satisfaction } \\
\text { was associated with stress } \\
\text { (Pearson's correlation } \\
\text { coefficient }=-0.2, \\
p<0.01 \text { ) }\end{array}$ \\
\hline $\begin{array}{l}\text { Ma et al. } \\
(2015)\end{array}$ & USA & $\begin{array}{l}\text { Cross- } \\
\text { sectional }\end{array}$ & $\begin{array}{l}2004- \\
2009\end{array}$ & $\begin{array}{l}365(72.6 \%, \\
41.2 \text { years })\end{array}$ & $\begin{array}{l}\text { Shift work } \\
\quad \text { (database of } \\
\text { payroll } \\
\text { records) }\end{array}$ & $\begin{array}{l}\text { Job stress } \\
\text { (Spielberger } \\
\text { Police Stress } \\
\text { Survey) }\end{array}$ & $\begin{array}{l}\text { Multivariate } \\
\text { linear } \\
\text { regression }\end{array}$ & $\begin{array}{l}\text { Shift work was associated } \\
\text { with stress }(p<0.05)\end{array}$ \\
\hline $\begin{array}{l}\text { Masilamanietal. } \\
\text { (2013) }\end{array}$ & Malaysia & $\begin{array}{l}\text { Cross- } \\
\text { sectional }\end{array}$ & 2011 & $\begin{array}{l}579(87.4 \%, \\
35.2 \text { years })\end{array}$ & $\begin{array}{l}\text { Demographic } \\
\text { characteris- } \\
\text { tics; job } \\
\text { characteristics }\end{array}$ & $\begin{array}{l}\text { Life stress } \\
\text { (Depression, } \\
\text { Anxiety and } \\
\text { Stress Scale, } \\
\text { DASS) }\end{array}$ & $\begin{array}{l}\text { Multivariate } \\
\text { logistic } \\
\text { regression }\end{array}$ & $\begin{array}{l}\text { Higher police rank } \\
\qquad \mathrm{OR}=10.68 ; 95 \% \\
\mathrm{CI}=3.51 \text { to } 32.53 \text { ) and } \\
\text { self-estimation that salary } \\
\text { is inappropriate regarding } \\
\text { duties (OR }=2.73 ; 95 \% \\
\mathrm{CI}=1.43 \text { to } 5.22 \text { ) were } \\
\text { associated with stress }\end{array}$ \\
\hline
\end{tabular}

(Continued) 
Appendix

(Continued)

\begin{tabular}{|c|c|c|c|c|c|c|c|c|}
\hline Reference $^{\mathrm{a}}$ & Country & $\begin{array}{l}\text { Study } \\
\text { design }\end{array}$ & $\begin{array}{l}\text { Year of } \\
\text { data col- } \\
\text { lection }\end{array}$ & $\begin{array}{l}\text { Number of } \\
\text { police } \\
\text { officers } \\
\text { (percentage } \\
\text { of males, } \\
\text { mean age) } \\
\end{array}$ & $\begin{array}{l}\text { Risk factors } \\
\text { (question- } \\
\text { naire) }\end{array}$ & $\begin{array}{l}\text { Outcome } \\
\text { (questionnaire) }\end{array}$ & $\begin{array}{l}\text { Level of } \\
\text { analysis }^{c}\end{array}$ & Main results \\
\hline $\begin{array}{l}\text { Kaur et al. } \\
\text { (2013) }\end{array}$ & India & $\begin{array}{l}\text { Cross- } \\
\text { sectional }\end{array}$ & 2013 & $\begin{array}{l}150(90 \%, 42 \\
\text { years })\end{array}$ & $\begin{array}{l}\text { Demographic } \\
\text { characteris- } \\
\text { tics; job } \\
\text { characteris- } \\
\text { tics; coping } \\
\text { strategies } \\
\text { (Coping } \\
\text { Checklist-1 } \\
\text { (CCL-1); } \\
\text { personality } \\
\text { traits } \\
\text { (Eysenck's } \\
\text { Personality } \\
\text { Questionnaire, } \\
\text { EPQ) }\end{array}$ & $\begin{array}{l}\text { Life stress } \\
\text { (General Health } \\
\text { Questionnaire, } \\
\text { GHQ) }\end{array}$ & Univariate & $\begin{array}{l}\text { Neuroticism }(p<0.001), \\
\text { psychotism }(p<0.001), \\
\text { extroversion }(p=0.023), \\
\text { negative distraction } \\
(p<0.001) \text { and } \\
\text { denial/blame }(p<0.001) \\
\text { were associated with } \\
\text { stress }\end{array}$ \\
\hline $\begin{array}{l}\text { Garbarino et } \\
\text { al. (2013) }\end{array}$ & Italy & $\begin{array}{l}\text { Cross- } \\
\text { sectional }\end{array}$ & 2009 & $\begin{array}{l}289(99.3 \% \\
35.4 \text { years })\end{array}$ & $\begin{array}{l}\text { Personality traits } \\
\text { (Big Five } \\
\text { Questionnaire, } \\
\text { BFQ) }\end{array}$ & $\begin{array}{l}\text { Job stress } \\
\text { (Demand/Contro } \\
\text { DCS; } \\
\text { Effort/Reward } \\
\text { Imbalance, ERI) }\end{array}$ & $\begin{array}{l}\text { Multivariate } \\
\text { opoitinear } \\
\text { regression }\end{array}$ & $\begin{array}{l}\text { Neuroticism }(\text { coefficient } \\
\mathrm{b}=0.12, p<0.05 \text { ) and } \\
\text { high agreeableness } \\
(\text { coefficient } \mathrm{b}=-0.16 \\
p<0.001 \text { ) were } \\
\text { associated with stress }\end{array}$ \\
\hline $\begin{array}{l}\text { Selokaretal. } \\
\quad(2011)\end{array}$ & India & $\begin{array}{l}\text { Cross- } \\
\text { sectional }\end{array}$ & 2009 & $\begin{array}{c}102(95.1 \%, \\
36 \text { years) }\end{array}$ & $\begin{array}{l}\text { Demographic } \\
\text { characteris- } \\
\text { tics; job } \\
\text { characteristics }\end{array}$ & $\begin{array}{l}\text { Job stress (The } \\
\text { Professional } \\
\text { Life Stress test) }\end{array}$ & Univariate & $\begin{array}{l}\text { Increased working hours } \\
\text { was associated with stress } \\
(p<0.001) \text { and married } \\
\text { experienced more stress } \\
(p<0.001)\end{array}$ \\
\hline $\begin{array}{l}\text { Gerber et al. } \\
\quad(2010)\end{array}$ & Switzerland & $\begin{array}{l}\text { Cross- } \\
\text { sectional }\end{array}$ & 2008 & $\begin{array}{l}460(74.8 \% \\
40.7 \text { years })\end{array}$ & Shift work & $\begin{array}{l}\text { Life and job stress } \\
\text { (Trier Inventory } \\
\text { for the } \\
\text { Assessment of } \\
\text { Chronic Stress, } \\
\text { TICS) }\end{array}$ & $\begin{array}{l}\text { Multivariate } \\
\text { analysis of } \\
\text { covariance }\end{array}$ & $\begin{array}{l}\text { Shift work was associated } \\
\text { with stress }(p<0.001)\end{array}$ \\
\hline
\end{tabular}




\begin{tabular}{|c|c|c|c|c|c|c|c|c|}
\hline $\begin{array}{l}\text { Žukauskasetal. } \\
\text { (2009) }\end{array}$ & Lithuania & $\begin{array}{l}\text { Cross- } \\
\text { sectional }\end{array}$ & 2003 & $\begin{array}{l}314(66.9 \%, \\
\text { NM) }\end{array}$ & $\begin{array}{l}\text { Operational and } \\
\text { organizational } \\
\text { job factors }\end{array}$ & $\begin{array}{l}\text { Job stress (a } \\
\text { yes/no question } \\
\text { about stress) }\end{array}$ & Univariate & $\begin{array}{l}\text { Violence against colleagues } \\
(p<0.05), \text { hoax calls } \\
(p<0.001), \text { crowd control } \\
(p<0.001) \text {, dealing with } \\
\text { rape victims }(p<0.05), \\
\text { using force }(p<0.001), \\
\text { negative public opinion } \\
(p<0.05) \text {, shift work } \\
(p<0.01) \text { and high work } \\
\text { demands }(p<0.05) \text { were } \\
\text { associated with stress }\end{array}$ \\
\hline $\begin{array}{l}\text { Gershonetal. } \\
\text { (2009) }\end{array}$ & USA & $\begin{array}{l}\text { Cross- } \\
\text { sectional }\end{array}$ & $\begin{array}{l}1999- \\
2000\end{array}$ & $\begin{array}{c}1072(85.7 \%, \\
36 \text { years })\end{array}$ & $\begin{array}{l}\text { Job characteris- } \\
\text { tics; coping } \\
\text { strategies } \\
\text { (Coping Scale } \\
\text { and Police } \\
\text { Coping Scale) }\end{array}$ & $\begin{array}{l}\text { Job stress (Police } \\
\text { Stress Scale) }\end{array}$ & $\begin{array}{l}\text { Multivariate } \\
\text { logistic } \\
\text { regression }\end{array}$ & $\begin{array}{l}\text { Negative coping strategy } \\
\text { (OR }=2.70,95 \% \\
\mathrm{CI}=2.03 \text { to } 3.60), \\
\text { avoidance coping strategy } \\
(\mathrm{OR}=2.68,95 \% \\
\mathrm{CI}=1.94 \text { to } 3.70) \text {, critical } \\
\text { incidents exposure } \\
(\mathrm{OR}=1.62,95 \% \\
\mathrm{CI}=1.21 \text { to } 2.15) \text {, poor } \\
\text { cooperation }(\mathrm{OR}=1.47, \\
95 \% \mathrm{CI}=1.11 \text { to } 1.97), \\
\text { workplace discrimination } \\
(\mathrm{OR}=1.64,95 \% \\
\mathrm{CI}=1.21 \text { to } 2.21) \text {, lack of } \\
\text { organizational fairness } \\
(\mathrm{OR}=1.92,95 \% \\
\mathrm{CI}=1.42 \text { to } 2.59) \text { and job } \\
\text { dissatisfaction } \\
(\mathrm{OR}=1.93,95 \% \\
\mathrm{CI}=1.44 \text { to } 2.60) \text { were } \\
\text { associated with stress }\end{array}$ \\
\hline $\begin{array}{l}\text { Berg et al. } \\
\text { (2005) }\end{array}$ & Norway & $\begin{array}{l}\text { Cross- } \\
\text { sectional }\end{array}$ & 2000 & $\begin{array}{l}3272(82.1 \% \\
\text { NM) }\end{array}$ & $\begin{array}{l}\text { Demographic } \\
\text { characteris- } \\
\text { tics; job } \\
\text { characteris- } \\
\text { tics; coping } \\
\text { strategies } \\
\text { (Coping } \\
\text { Strategies } \\
\text { Scale of the } \\
\text { Pressure } \\
\text { Management } \\
\text { Indicator) }\end{array}$ & $\begin{array}{l}\text { Job stress (The } \\
\text { Job Stress } \\
\text { Survey, JSS) }\end{array}$ & $\begin{array}{l}\text { Multivariate } \\
\text { linear } \\
\text { regression }\end{array}$ & $\begin{array}{l}\text { Increased age }(p<0.05), \\
\text { higher police rank } \\
(p<0.05) \text {, male gender } \\
(p<0.05) \text {, police officers } \\
\text { who worked in districts } \\
\text { with }>50,000 \text { inhabitants } \\
(p<0.05) \text {, neuroticism } \\
(p<0.05) \text {, lack of control } \\
(p<0.01) \text { and reality } \\
\text { weakness }(p<0.01) \text { were } \\
\text { associated with stress }\end{array}$ \\
\hline
\end{tabular}


Appendix

(Continued)

\begin{tabular}{|c|c|c|c|c|c|c|c|c|}
\hline Reference $^{\mathrm{a}}$ & Country & $\begin{array}{l}\text { Study } \\
\text { design }\end{array}$ & $\begin{array}{l}\text { Year of } \\
\text { data col- } \\
\text { lection }\end{array}$ & $\begin{array}{l}\text { Number of } \\
\text { police } \\
\text { officers } \\
\text { (percentage } \\
\text { of males, } \\
\text { mean age) }\end{array}$ & $\begin{array}{l}\text { Risk factors }{ }^{b} \\
\text { (question- } \\
\text { naire) }\end{array}$ & $\begin{array}{l}\text { Outcome } \\
\text { (questionnaire) }\end{array}$ & $\begin{array}{l}\text { Level of } \\
\text { analysis }^{c}\end{array}$ & Main results \\
\hline $\begin{array}{l}\text { Collins \& } \\
\text { Gibbs } \\
(2003)\end{array}$ & $\begin{array}{l}\text { United } \\
\text { King- } \\
\text { dom }\end{array}$ & $\begin{array}{l}\text { Cross- } \\
\text { sectional }\end{array}$ & 2003 & $\begin{array}{c}873(80 \%, \\
\text { NM) }\end{array}$ & $\begin{array}{c}\text { Operational and } \\
\text { organizational } \\
\text { job factors }\end{array}$ & $\begin{array}{l}\text { Life stress } \\
\text { (General Health } \\
\text { Questionnaire, } \\
\text { GHQ) }\end{array}$ & $\begin{array}{l}\text { Multivariate } \\
\text { logistic } \\
\text { regression }\end{array}$ & $\begin{array}{l}\text { Demands of work } \\
\text { impinging on home } \\
(p<0.00001), \text { lack of } \\
\text { support from senior } \\
\text { officers }(p=0.00006), \\
\text { dealing with someone } \\
\text { who is drunk } \\
(p=0.0009), \text { subject to a } \\
\text { complaints investigator } \\
(p=0.003), \text { being at risk } \\
\text { of hepatitis or AIDS } \\
(p=0.005), \text { not enough } \\
\text { control over work } \\
(p=0.005) \text { and urgent } \\
\text { requests preventing } \\
\text { planned work }(p=0.02) \\
\text { were associated with } \\
\text { stress }\end{array}$ \\
\hline $\begin{array}{l}\text { Deschamps et } \\
\text { al. (2003) }\end{array}$ & France & $\begin{array}{l}\text { Cross- } \\
\text { sectional }\end{array}$ & $\begin{array}{l}1999- \\
2000\end{array}$ & $\begin{array}{l}617(84 \%, \\
39.9 \text { years })\end{array}$ & $\begin{array}{l}\text { Demographic } \\
\text { characteris- } \\
\text { tics; job } \\
\text { characteris- } \\
\text { tics; lifestyle } \\
\text { factors }\end{array}$ & $\begin{array}{l}\text { Life and job stress } \\
\text { (visual analogue } \\
\text { scale) }\end{array}$ & $\begin{array}{l}\text { Multivariate } \\
\text { logistic } \\
\text { regression }\end{array}$ & $\begin{array}{l}\text { Increased years of } \\
\text { experience }(\mathrm{OR}=5.72, \\
95 \% \mathrm{CI}=2.52 \text { to } 12.98, \\
p<0.0001), \text { lack of } \\
\text { hobbies }(\mathrm{OR}=1.93,95 \% \\
\mathrm{CI}=1.31 \text { to } 2.85, \\
p=.001) \text { and lack of } \\
\text { sports }(\mathrm{OR}=1.53,95 \% \\
\mathrm{CI}=1.04 \text { to } 2.26, p=.03) \\
\text { were associated with } \\
\text { stress }\end{array}$ \\
\hline $\begin{array}{l}\text { Gershonetal. } \\
\text { (2002) }\end{array}$ & USA & $\begin{array}{l}\text { Cross- } \\
\text { sectional }\end{array}$ & 2002 & $\begin{array}{c}105(98.1 \%, \\
53.5 \text { years })\end{array}$ & $\begin{array}{l}\text { Job characteris- } \\
\text { tics; coping } \\
\text { strategies } \\
\text { [questionnaire } \\
\text { adapted from } \\
\text { scales } \\
\text { developed by } \\
(105,106)]\end{array}$ & $\begin{array}{l}\text { Job stress }(11 \\
\text { items adapted } \\
\text { from the } \\
\text { National } \\
\text { Institutes for } \\
\text { Occupational } \\
\text { Safety and } \\
\text { Health work } \\
\text { stress scale) }\end{array}$ & $\begin{array}{l}\text { Multivariate } \\
\text { logistic } \\
\text { regression }\end{array}$ & $\begin{array}{l}\text { Exposure to critical } \\
\text { incidents }(\mathrm{OR}=3.71, \\
95 \% \mathrm{CI}=1.26 \text { to } 10.9) \\
\text { and maladaptive coping } \\
\text { behaviors }(\mathrm{OR}=5.35, \\
95 \% \mathrm{CI}=1.75 \text { to } 16.35) \\
\text { were associated with } \\
\text { stress }\end{array}$ \\
\hline
\end{tabular}




\begin{tabular}{|c|c|c|c|c|c|c|c|c|}
\hline $\begin{array}{l}\text { He et al. } \\
\text { (2002) }\end{array}$ & USA & $\begin{array}{l}\text { Cross- } \\
\text { sectional }\end{array}$ & $\begin{array}{l}1999- \\
2000\end{array}$ & $\begin{array}{l}1100(85.7 \% \\
\mathrm{NM})\end{array}$ & $\begin{array}{l}\text { Lifestyle } \\
\text { factors; } \\
\text { coping } \\
\text { strategies (e.g. } \\
\text { talk to } \\
\text { family/friends } \\
\text { about the } \\
\text { problem, } \\
\text { planning, stay } \\
\text { away from } \\
\text { everyone, } \\
\text { smash or } \\
\text { break things) }\end{array}$ & $\begin{array}{l}\text { Life stress (a } \\
\text { modified } \\
\text { version of the } \\
\text { Brief Symptom } \\
\text { Inventory, BSI) }\end{array}$ & $\begin{array}{l}\text { Multivariate } \\
\text { linear } \\
\text { regression }\end{array}$ & $\begin{array}{l}\text { Negative work environment } \\
\text { (coefficient } \mathrm{b}=0.157, \\
p<0.05 \text { for males), } \\
\text { work-family conflict } \\
\text { (coefficient } \mathrm{b}=0.227, \\
p<0.05 \text { for males and } \\
\text { coefficient } \mathrm{b}=0.174, \\
p<0.05 \text { for females) and } \\
\text { negative coping strategies } \\
\text { (coefficient } \mathrm{b}=0.238, \\
p<0.05 \text { for males and } \\
\text { coefficient } \mathrm{b}=0.345, \\
p<0.05 \text { for females) were } \\
\text { associated with stress }\end{array}$ \\
\hline $\begin{array}{l}\text { Zhao et al. } \\
\text { (2002) }\end{array}$ & USA & $\begin{array}{l}\text { Cross- } \\
\text { sectional }\end{array}$ & 1996 & $\begin{array}{l}345(100 \% \\
\text { NM) }\end{array}$ & $\begin{array}{l}\text { Job } \\
\text { characteristics }\end{array}$ & $\begin{array}{l}\text { Life stress (Brief } \\
\quad \text { Symptom } \\
\text { Inventory, BSI) }\end{array}$ & $\begin{array}{l}\text { Multivariate } \\
\text { linear } \\
\text { regression }\end{array}$ & $\begin{array}{l}\text { Bureaucracy (coefficient } \\
\mathrm{b}=0.15, p<0.05 \text { ) and } \\
\text { decreased feedback } \\
\text { (coefficient } \mathrm{b}=-0.20 \text {, } \\
p<0.05 \text { ) were associated } \\
\text { with stress }\end{array}$ \\
\hline $\begin{array}{c}\text { Patterson } \\
\quad(2001)\end{array}$ & USA & $\begin{array}{l}\text { Cross- } \\
\text { sectional }\end{array}$ & 2001 & $\begin{array}{l}233(89 \%, 37 \\
\text { years) }\end{array}$ & $\begin{array}{l}\text { Coping } \\
\text { strategies } \\
\text { (Ways of } \\
\text { Coping } \\
\text { Questionnaire, } \\
\text { WAYS); life } \\
\text { stressors (13 } \\
\text { items } \\
\text { measure) } \\
(107)\end{array}$ & $\begin{array}{l}\text { Life stress (15 } \\
\text { items measure) } \\
(107)\end{array}$ & $\begin{array}{l}\text { Multivariate } \\
\text { linear } \\
\text { regression }\end{array}$ & $\begin{array}{l}\text { Life stressors (coefficient } \\
\mathrm{b}=0.51, p<0.001 \text { ) and } \\
\text { negative } \\
\text { (emotion-focused) coping } \\
\text { strategies (coefficient } \\
\mathrm{b}=0.18, p<0.05 \text { ) were } \\
\text { associated with stress }\end{array}$ \\
\hline $\begin{array}{c}\text { Brownetal. } \\
\text { (1996) }\end{array}$ & $\begin{array}{l}\text { United } \\
\text { King- } \\
\text { dom }\end{array}$ & $\begin{array}{l}\text { Cross- } \\
\text { sectional }\end{array}$ & 1992 & $\begin{array}{l}810(97 \%, \\
47.1 \text { years })\end{array}$ & $\begin{array}{l}\text { Job satisfaction } \\
\text { ( } 22 \text { items, e.g. } \\
\text { being valued, } \\
\text { salary); } \\
\text { coping } \\
\text { strategies ( } 28 \\
\text { items, e.g. } \\
\text { planning, } \\
\text { dealing with } \\
\text { problems } \\
\text { immediately) }\end{array}$ & $\begin{array}{l}\text { Job stress } \\
\text { (Occupational } \\
\text { Stress Indicator, } \\
\text { OSI) }\end{array}$ & Univariate & $\begin{array}{l}\text { External locus of control } \\
\text { (Pearson's correlation } \\
\text { coefficient }=0.21, \\
p<0.001 \text { ) and lack of } \\
\text { positive coping strategies } \\
\text { (Pearson's correlation } \\
\text { coefficient }=0.1, p<0.05 \text { ) } \\
\text { were associated with } \\
\text { stress }\end{array}$ \\
\hline
\end{tabular}

(Continued) 
Appendix

\begin{tabular}{|c|c|c|c|c|c|c|c|c|}
\hline \multicolumn{9}{|c|}{$\begin{array}{l}\text { Appendix } \\
\text { (Continued) }\end{array}$} \\
\hline Reference $^{a}$ & Country & $\begin{array}{l}\text { Study } \\
\text { design }\end{array}$ & $\begin{array}{l}\text { Year of } \\
\text { data col- } \\
\text { lection }\end{array}$ & $\begin{array}{l}\text { Number of } \\
\text { police } \\
\text { officers } \\
\text { (percentage } \\
\text { of males, } \\
\text { mean age) }\end{array}$ & $\begin{array}{l}\text { Risk factors } \\
\text { (question- } \\
\text { naire) }\end{array}$ & $\begin{array}{l}\text { Outcome } \\
\text { (questionnaire) }\end{array}$ & $\begin{array}{l}\text { Level of } \\
\text { analysis }^{c}\end{array}$ & Main results \\
\hline $\begin{array}{r}\text { Violanti } \\
\text { (1992) }\end{array}$ & USA & $\begin{array}{l}\text { Cross- } \\
\text { sectional }\end{array}$ & 1992 & $\begin{array}{l}180(90 \%, \\
23.1 \text { years })\end{array}$ & $\begin{array}{l}\text { Coping } \\
\text { strategies } \\
\text { (Ways of } \\
\text { Coping Check } \\
\text { List, WCCL); } \\
\text { life stressors } \\
\text { (Social } \\
\text { Readjustment } \\
\text { Scale) }\end{array}$ & $\begin{array}{l}\text { Life stress (Center } \\
\text { for } \\
\text { Epidemiological } \\
\text { Studies } \\
\text { Depression } \\
\text { Scale, CES-D) }\end{array}$ & $\begin{array}{l}\text { Multivariate } \\
\text { linear } \\
\text { regression }\end{array}$ & $\begin{array}{l}\text { Escape/avoidance } \\
\text { (coefficient } \mathrm{b}=0.33 \\
p<0.05 \text { ) and self-control } \\
\text { coping coefficient } \\
\mathrm{b}=0.32, p<0.05 \text { ) were } \\
\text { associated with stress }\end{array}$ \\
\hline $\begin{array}{l}\text { Brown \& } \\
\text { Campbell } \\
\text { (1990) }\end{array}$ & $\begin{array}{l}\text { United } \\
\text { King- } \\
\text { dom }\end{array}$ & $\begin{array}{l}\text { Cross- } \\
\text { sectional }\end{array}$ & 1989 & $\begin{array}{l}954 \text { ( } 80 \%, \\
\quad 36.4 \text { years) }\end{array}$ & $\begin{array}{l}\text { Demographic } \\
\text { characteris- } \\
\text { tics; job } \\
\text { characteris- } \\
\text { tics; lifestyle } \\
\text { factors }\end{array}$ & $\begin{array}{l}\text { Life stress } \\
\text { (General Health } \\
\text { Questionnaire, } \\
\text { GHQ) }\end{array}$ & Univariate & $\begin{array}{l}\text { Lower police rank was } \\
\text { associated with stress } \\
(p<0.001)\end{array}$ \\
\hline $\begin{array}{l}\text { White et al. } \\
\text { (1985) }\end{array}$ & USA & $\begin{array}{l}\text { Cross- } \\
\text { sectional }\end{array}$ & 1980 & $\begin{array}{c}232(93.5 \% \\
35.8 \text { years) }\end{array}$ & $\begin{array}{l}\text { Demographic } \\
\text { characteris- } \\
\text { tics; job } \\
\text { characteris- } \\
\text { tics; burnout } \\
\text { (Maslach } \\
\text { Burnout } \\
\text { Inventory, } \\
\text { MBI); coping } \\
\text { strategies } \\
\text { measurement } \\
\text { (108) }\end{array}$ & $\begin{array}{l}\text { Job stress } \\
\text { (modified } \\
\text { Spielberger } \\
\text { Police Stress } \\
\text { Survey) }\end{array}$ & Univariate & $\begin{array}{l}\text { Decreased years of } \\
\text { experience }(p<0.01), \\
\text { burnout }(p<0.05), \\
\text { decreased physical } \\
\text { activity }(p<0.05), \\
\text { decreased hours of } \\
\text { hobbies }(p<0.05) \text { and } \\
\text { negative coping strategy } \\
(p<0.05) \text { were associated } \\
\text { with stress }\end{array}$ \\
\hline
\end{tabular}

NM: non mentioned; OR: Odds Ratio; CI: Confidence Interval. ${ }^{a}$ Arrangement in publication year order. ${ }^{b}$ Demographic characteristics: gender, age, marital status, children, educational level. Job characteristics: years of experience, rank, working hours, shift work, job satisfaction, workload, salary, work environment, support from colleagues/superiors, operational and organizational factors. Lifestyle factors: sleep duration, physical activity, smoking, alcohol, work-family conflict, health state. Demographic characteristics, job characteristics and lifestyle factors were self-reported in all studies. ${ }^{c}$ Univariate analysis does not eliminate confounders, while multivariate analysis eliminates confounders, decreasing so the systematic bias. 